\title{
Establishment and characterisation of fantail goldfish fin (FtGF) cell line from goldfish, Carassius auratus for in vitro propagation of Cyprinid herpes virus -2 (CyHV-2)
}

Arathi Dharmaratnam ${ }^{1}$, Raj Kumar ${ }^{1}$, Basheer Saidmuhammed Valaparambil ${ }^{1}$, Neeraj Sood ${ }^{2}$, Pravata Kumar Pradhan $^{2}$, Sweta Das ${ }^{1}$, T Raja Swaminathan ${ }^{\text {Corresp. } 1}$

${ }^{1}$ Peninsular and Marine Fish Genetic Resources Centre, ICAR National Bureau of Fish Genetic Resources, Kochi, Kerala, India

ICAR National Bureau of Fish Genetic Resources, Lucknow, Uttar Pradesh, India

Corresponding Author: T Raja Swaminathan

Email address: Thangaraj.swaminathan@icar.gov.in

Background: Herpesviral haematopoietic necrosis disease, caused by cyprinid herpesvirus-2 (CyHV-2), is responsible for massive mortalities in the aquaculture of goldfish, Carassius auratus. Permissive cell lines for the isolation and propagation of CyHV-2 have been established from various goldfish tissues by sacrificing the fish. Here, we report the development of a cell line, FtGF (Fantail Goldfish Fin) from caudal fin of goldfish using non-lethal sampling. We also describe a simple protocol for successful establishment and characterization of a permissive cell line through explant method and continuous propagation of CyHV-2 with high viral titre using this cell line. Methods: Caudal fin tissue samples were collected from goldfish without killing the fish. Cell culture of goldfish caudal fin cells was carried out using Leibovitz's L-15 (L-15) medium containing $20 \%$ FBS and $1 \mathrm{X}$ concentration of antibiotic antimycotic solution, incubated at $28{ }^{\circ} \mathrm{C}$. Cells were characterized and origin of the cells was confirmed by sequencing fragments of the $16 \mathrm{~S}$ rRNA and COI genes. CyHV-2 was grown in the FtGF cells and passaged continuously 20 times. The infectivity of the CyHV-2 isolated using FtGF cells was confirmed by experimental infection of naïve goldfish Results: The cell line has been passaged up to 56 times in L-15 with $10 \%$ FBS. Karyotyping of FtGF cells at $30^{\text {th }} 40^{\text {th }}$ and $56^{\text {th }}$ passage indicated that modal chromosome number was $2 n=104$. Species authentication of FtGF was performed by sequencing of the 16S rRNA and COI genes. The cell line was used for continuous propagation of CyHV-2 over 20 passages with high viral titer of $10^{7.8 \pm 0.26}$ $\mathrm{TCID}_{50} / \mathrm{mL}$. Following inoculation of CyHV-2 positive tissue homogenate, FtGF cells showed cytopathic effect by $2^{\text {nd }}$ day post-inoculation (dpi) and complete destruction of cells was observed by the $10^{\text {th }} \mathrm{dpi}$. An experimental infection of naïve goldfish using supernatant from infected FtGF cells caused $100 \%$ mortality and CyHV-2 infection in the challenged fish 
was confirmed by the amplification of DNA polymerase gene, histopathology and transmission electron microscopy. These findings provide confirmation that the FtGF cell line is highly permissive to the propagation of CyHV-2. 
1 Title: Establishment and characterisation of fantail goldfish fin (FtGF) cell line from goldfish,

2 Carassius auratus for in vitro propagation of Cyprinid herpes virus -2 (CyHV-2).

\section{Authors and Addresses:}

4 Arathi Dharmaratnam ${ }^{\mathrm{a}}$, Raj Kumar ${ }^{\mathrm{a}}$, Valaparambil Saidmuhammed Basheer ${ }^{\mathrm{a}}$, Neeraj Sood ${ }^{\mathrm{b}}$,

5 Pravata Kumar Pradhan ${ }^{b}$, Sweta Das $^{\mathrm{a}}$ and Thangaraj Raja Swaminathan ${ }^{\mathrm{a}^{*}}$

6 aPeninsular and Marine Fish Genetic Resources Centre, ICAR National Bureau of Fish Genetic

7 Resources, CMFRI Campus, Kochi, Kerala, India - 682018.

8 bICAR National Bureau of Fish Genetic Resources, Canal Ring Road, P.O. Dilkusha, Lucknow,

9 Uttar Pradesh, India - 226002

10 Running page head: CyHV-2 isolation in India

$11 *$ Corresponding author:

12 Dr. T. Raja Swaminathan

13 Peninsular and Marine Fish Genetic Resources Centre

14 ICAR-NBFGR, CMFRI Campus

15 P.O. Number 1603, Kochi

16 Kerala 682018, India

17 E-mail: Thangaraj.Swaminathan@icar.gov.in 
19 Abstract

\section{Background:}

Herpesviral haematopoietic necrosis disease, caused by cyprinid herpesvirus-2 (CyHV-2), is responsible for massive mortalities in the aquaculture of goldfish, Carassius auratus. Permissive cell lines for the isolation and propagation of CyHV-2 have been established from various goldfish tissues by sacrificing the fish. Here, we report the development of a cell line, FtGF (Fantail Goldfish Fin) from caudal fin of goldfish using non-lethal sampling. We also describe a simple protocol for successful establishment and characterization of a permissive cell line through explant method and continuous propagation of CyHV-2 with high viral titre using this cell line.

\section{Methods:}

Caudal fin tissue samples were collected from goldfish without killing the fish. Cell culture of goldfish caudal fin cells was carried out using Leibovitz's L-15 (L-15) medium containing 20\% FBS and $1 \mathrm{X}$ concentration of antibiotic antimycotic solution, incubated at $28{ }^{\circ} \mathrm{C}$. Cells were characterized and origin of the cells was confirmed by sequencing fragments of the 16S rRNA and COI genes. CyHV-2 was grown in the FtGF cells and passaged continuously 20 times. The infectivity of the CyHV-2 isolated using FtGF cells was confirmed by experimental infection of naïve goldfish

\section{Results:}

38 The cell line has been passaged up to 56 times in L-15 with 10\% FBS. Karyotyping of FtGF cells 39 at $30^{\text {th }} 40^{\text {th }}$ and $56^{\text {th }}$ passage indicated that modal chromosome number was $2 \mathrm{n}=104$. Species authentication of FtGF was performed by sequencing of the 16S rRNA and COI genes. The cell 41 line was used for continuous propagation of CyHV-2 over 20 passages with high viral titer of 
$4210^{7.8 \pm 0.26} \mathrm{TCID}_{50} / \mathrm{mL}$. Following inoculation of CyHV-2 positive tissue homogenate, FtGF cells

43 showed cytopathic effect by $2^{\text {nd }}$ day post-inoculation (dpi) and complete destruction of cells was

44 observed by the $10^{\text {th }}$ dpi. An experimental infection of naïve goldfish using supernatant from

45 infected FtGF cells caused 100\% mortality and CyHV-2 infection in the challenged fish was

46 confirmed by the amplification of DNA polymerase gene, histopathology and transmission

47 electron microscopy. These findings provide confirmation that the FtGF cell line is highly

48 permissive to the propagation of $\mathrm{CyHV}-2$.

49 Introduction

50 Cyprinid herpesvirus-2 (CyHV-2), the etiological agent of herpesviral haematopoietic necrosis

51 (HVHN) disease, is a pathogen of goldfish that has been associated with disease outbreaks in

52 goldfish culture (Jeffery et al., 2007). The pathogen first reported as the cause of outbreaks in

53 juvenile goldfish in 1992 from Japan (Jung \& Miyazaki, 1995), has subsequently been reported

54 from more than 13 countries (Adamek et al., 2018). In India, CyHV-2 infection was associated

55 with large-scale mortalities of goldfish in West Bengal (Sahoo et al., 2016). As the surviving fish

56 become lifelong carriers of latent infection without exhibiting any clinical signs of the disease

57 (Wang et al., 2012) and goldfish are one of the most traded ornamental fish globally, the

58 international trade of such apparently healthy but latently infected goldfish is suspected to be

59 responsible for the global spread of CyHV-2 (Ito et al., 2013; Adamek et al., 2018).

Cell lines are considered the gold standard for isolation and identification of viruses

61 (Landry, 2009). Earlier, a number of cell lines from other fish species, namely Epithelioma

62 papulosum cyprini cells (EPC), fathead minnow cells (FHM) and koi fin cell lines (KF-1) have

63 been used for CyHV-2 cultivation, but these cell lines did not support its continuous propagation

64 beyond $5^{\text {th }}$ passage (Jeffery et al., 2007; Wang et al., 2012). In an earlier study from India, the 
65 virus could not be propagated beyond $4^{\text {th }}$ passage, despite producing cytopathic effects in CCKF 66 cell line (Sahoo et al., 2016),. It has been reported that cell lines derived from homologous

67 species provide sensitive tools for virus propagation (Fryer \& Lannan, 1994) and successful 68 cultivation of CyHV-2 has been reported in cell lines developed from goldfish, namely GFTF 69 (Yan, Nie \& Lu, 2011), GFF and SRTF (Ito et al., 2013) and GiCB (Ma et al., 2015). More than 7015 cell lines have been developed globally from different goldfish tissues since 1964 (Table.1).

71 However, no cell line from goldfish is available in India, therefore, the need of establishing a 72 homologous cell line from goldfish was deemed necessary for the continuous propagation and 73 study of CyHV-2.

In this paper, we report the development of a cell line from the caudal fin of fantail goldfish (FtGF). The cell line has been successfully employed for propagation of CyHV-2, and experimental reproduction of HVHN using supernatant from the CyHV-2 infected cell line (at $10^{\text {th }}$ passage). The newly developed FtGF cell line will play significant role in future research on CyHV-2, including the development of strategies for the prevention and control of the disease caused by CyHV-2 in India.

\section{Materials and methods}

\section{Generation of the primary cell culture}

A healthy fantail goldfish weighing $20 \mathrm{~g}$ was purchased from a local commercial aquarium shop and kept in properly aerated and filtered fish tank. The fish was fed daily and water changes were performed on alternate days. The goldfish was anaesthetized using 3- aminobenzoic acid ethyl ester methanesulphonate (MS-222, Sigma-Aldrich, St. Louis, MO) at the dose rate of $150 \mathrm{mg} / \mathrm{L}$ of water and the caudal fin was excised after wiping with $70 \%$ ethanol. The excised tissue was washed three times in Phosphate Buffer Saline (PBS) (Life Technologies, Carlsbad, CA; Lot 
88 number - 1967526; Catalogue number - 14190-144 500mL) containing antibiotic-antimycotic

89 solution (200 IU/mL penicillin, $200 \mu \mathrm{g} / \mathrm{mL}$ streptomycin and $0.5 \mu \mathrm{g} / \mathrm{mL}$ amphotericin B) (Life

90 Technologies, Carlsbad, CA; Lot number - 2112695; Catalogue number - 15240-062 $100 \mathrm{~mL}$ ).

91 The fin tissue was mechanically cut with a fine scalpel into smaller pieces and then seeded in a

$9225 \mathrm{~cm}^{2}$ flask. The PBS was removed and attachment of the tissues to the surface was facilitated

93 by adding $200 \mu 1$ of fetal bovine serum (FBS) (Life Technologies, Carlsbad, CA; Lot number -

94 42G829K; Catalogue number - 10270-106 $500 \mathrm{~mL}$ ). After $2 \mathrm{~h}$, about $7 \mathrm{~mL}$ of Leibovitz's L-15

95 (L-15) medium (Life Technologies, Carlsbad, CA; Lot number - 2085192; Catalogue number -

96 11415-064 $500 \mathrm{~mL}$ ) containing 20\% FBS and 1X concentration of antibiotic antimycotic

97 solution was added to the flask, which was then incubated at $28^{\circ} \mathrm{C}$. The flask was observed daily

98 under an inverted light microscope (Nikon Corporation, Tokyo, Japan).

\section{Subculture and maintenance}

100 After formation of monolayer, the cells were washed with PBS followed by trypsinization with $101 \quad 0.25 \%$ trypsin EDTA solution (Life Technologies, Carlsbad, CA; Lot number - 2053183;

102 Catalogue number - 15400-054 $100 \mathrm{~mL}$ ). The cells were observed under an inverted light 103 microscope. The trypsin EDTA solution was discarded immediately on observing cell 104 detachment. The flasks were gently tapped to release the cells from the surface and L-15 medium 105 with $20 \%$ FBS was added to stop the action of trypsin. The cells were subcultured at a split ratio 106 of 1:2. The flasks were observed regularly and the cells were subcultured after attaining 80-90\% 107 confluence. After 10 subcultures, the concentration of FBS in medium was reduced to $10 \%$.

\section{Cell growth characteristics}

109 Cell growth studies were conducted at different temperatures and FBS concentrations in L-15 110 medium. The growth rate assays were conducted at temperatures ranging from $20{ }^{\circ} \mathrm{C}$ to $37{ }^{\circ} \mathrm{C}$ 
111 and FBS concentrations from 5\%-20\%. A monolayer flask at $20^{\text {th }}$ passage was trypsinized and

112 the cells were seeded into different 6 well plates. The plates were incubated overnight at $28{ }^{\circ} \mathrm{C}$.

113 Thereafter, the plates were incubated at different temperatures of $20{ }^{\circ} \mathrm{C}, 24{ }^{\circ} \mathrm{C}, 28{ }^{\circ} \mathrm{C}, 35^{\circ} \mathrm{C}$ and

$11437^{\circ} \mathrm{C}$ and the growth rate was observed. Cells were harvested from the duplicate wells daily and

115 counted with a Neubauer haemocytometer. A similar study was conducted using different 6 well

116 plates incubated at $28{ }^{\circ} \mathrm{C}$ having different FBS concentrations of $5 \%, 7.5 \%, 10 \%, 15 \%$ and $20 \%$.

117 The cells at $25^{\text {th }}$ passage at the concentration of $1 \times 10^{5}$ cells per ml were seeded into 24 -well

118 plates and cultured for $7 \mathrm{~d}$ at $28^{\circ} \mathrm{C}$. The cells were harvested, the number of cells in each well

119 counted with a hemocytometer, and the average value of 3 wells at each time was used to plot

120 the growth curve. The growth curve experiment of FtGF cells was repeated two times. Cell

121 growth curves were plotted, and the population doubling time (PDT) was calculated based on the

122 growth curve (Weingartl et al., 2002). Growth characteristic experiment assays were carried out

123 for $8 \mathrm{~d}$, and cell number was represented as mean \pm standard deviation (SD).

\section{Chromosome analysis}

125 The chromosomal counts for FtGF were undertaken from the $30^{\text {th }}, 40^{\text {th }}$ and $56^{\text {th }}$ passage flasks. A

126 flask with $80 \%$ confluence was treated with $1 \mu \mathrm{g} / \mathrm{mL}$ colchicine (Sigma, St Louis, MO, USA) for

$1274 \mathrm{~h}$ at $28{ }^{\circ} \mathrm{C}$ and then the supernatant was removed, the cells harvested and resuspended in a

128 hypotonic $0.5 \% \mathrm{KCl}$ solution for $10 \mathrm{~min}$, and then fixed in a 3:1 methanol : acetic acid solution.

129 The cells were pelleted at $367 \mathrm{~g}$ at $4{ }^{\circ} \mathrm{C}$ for $10 \mathrm{~min}$ and washed four times with methanol and

130 acetic acid solution. Smears were prepared following a conventional drop-splash technique

131 (Freshney, 2010), the slides were stained with $10 \%$ Giemsa solution and air dried for 30 min. A

132 total of 100 chromosome spreads were observed and counted under a light microscope (Leica, 133 Germany). 


\section{Cryopreservation}

135 The monolayers with $80-90 \%$ confluency were used for cryopreservation at various intervals 136 of subculturing $\left(7^{\text {th }}, 10^{\text {th }}, 20^{\text {th }}, 30^{\text {th }}\right.$ and $\left.40^{\text {th }}\right)$. The media was changed one day prior to 137 cryopreservation. Next day, the cells were trypsinised in PBS and centrifuged at $500 \mathrm{~g}$ at $4{ }^{\circ} \mathrm{C}$. at 138 a density of $5 \times 10^{6}$ cells $/ \mathrm{mL}$, Briefly, the flask was examined using an inverted microscope to 139 monitor the confluence and to check for microbial contamination if any. The spent cell culture 140 medium was removed. The cell monolayer was washed with a balanced PBS salt solution 141 without calcium and magnesium three times and ensuring the adherence of the cells. One ml of $1420.25 \%$ trypsin EDTA was added to the $25 \mathrm{~cm}^{2}$ surface area flask to cover the monolayer. Excess 143 solution was discarded and the flask was incubated at $37^{\circ} \mathrm{C}$ for $4 \mathrm{~min}$. with gentle rocking. The 144 flask was examined for the detachment of cells, the remaining cells were released with gentle 145 tapping and cells were re-suspended in L-15 medium with 20\% FBS to deactivate the trypsin.

146 The harvested cells were dispersed by repeated mild pipetting and cells were counted (Freshney, 147 2010). The cells were suspended in recovery cell-culture freezing medium (Life Technologies, 148 Carlsbad, CA; Lot number - 492531; Catalogue number - 12648-010 $50 \mathrm{~mL}$ ) aliquoted into 2 $149 \mathrm{~mL}$ sterile cryovials (Nunc), kept at $4{ }^{\circ} \mathrm{C}$ for $2 \mathrm{~h},-20{ }^{\circ} \mathrm{C}$ for $1 \mathrm{~h},-80{ }^{\circ} \mathrm{C}$ overnight and then 150 transferred into liquid nitrogen $\left(\mathrm{LN}_{2}\right)$ containers. The cells stored at $20^{\text {th }}$ and $40^{\text {th }}$ passage were 151 revived after 2 months of storage. Briefly, the frozen cells were thawed quickly at $37^{\circ} \mathrm{C}$ and 152 added drop-wise to $15 \mathrm{~mL}$ complete medium in a centrifuge tube. The cells were centrifuged at $153825 \mathrm{~g}$ at $4{ }^{\circ} \mathrm{C}$ and the pellet was resuspended in $7 \mathrm{~mL}$ of complete medium. Cell viability was 154 checked with a haemocytometer following trypan blue staining. The revived cells were seeded 155 into $25 \mathrm{~cm}^{2}$ flask and incubated at $28^{\circ} \mathrm{C}$.

\section{Transfection assays}



immunophenotyping of cells and transfection studies. FtGF cells in 20 fields were counted randomly and the percentage of positive green fluorescent protein (GFP) cells was calculated.

\section{Molecular characterization of the cell line}

DNA isolation was carried out by salting out method following Miller, Dykes \& Polesky (1988).

The DNA was extracted from FtGF cells at $40^{\text {th }}$ passage and muscle tissue of goldfish. PCR was

carried out as per Swaminathan et al., (2016b). PCR products of $562 \mathrm{bp}$ and $642 \mathrm{bp}$ were

amplified for mitochondrial 16S rRNA and cytochrome c oxidase subunit I (COI) genes using universal primers ((F 5'CGC CTG TTT ATC AAA AAC AT 3'and H 5'CCG GTC TGA ACT

(Palumbi et al., 1991) respectively. The PCR products of both the fragments were sequenced in an ABI 3730 DNA analyser (Applied Biosystems). The sequences of both the mt DNA gene

172 PCR fragments were compared with the published and known sequences in the National Centre for Biotechnology Information (NCBI) database by the basic local alignment search tool (BLAST) (Altschul et al., 1990).

\section{Detection of Mycoplasma contamination in FtGF cell line}

Mycoplasma contamination was tested by PCR with $15^{\text {th }}$ and $40^{\text {th }}$ passage FtGF cells grown for 4 days in L-15 medium without antibiotics. Briefly, the harvested cells were centrifuged at $200 \mathrm{~g}$

$179 g$ to remove debris. The Mycoplasma contamination was checked using EZdetect PCR Kit 
180 (HiMedia) based on amplification of spacer region between 16S rRNA and 23S rRNA. The 181 amplification products were analysed in $1.5 \%$ agarose gel.

\section{CyHV-2 isolation on FtGF cells and viral titer determination}

183 Diseased goldfish obtained from a farm in Kerala, India were confirmed to be infected with CyHV-2 by PCR as per Jeffery et al. (2007). External examination of moribund goldfish revealed clinical signs including simple loss of scales, pale mucous covered gills. Internally, all visceral organs of affected fish were congested and enlarged and white nodules were found on the spleen and the kidney. Gill, kidney and spleen tissues from diseased fish were collected aseptically, and then homogenized in Dulbecco's Phosphate Buffered Saline (DPBS), freezethawed for 3 cycles and the tissue homogenate was centrifuged at $3000 \mathrm{~g}$ for $30 \mathrm{~min}$ at $4{ }^{\circ} \mathrm{C}$. The supernatant was then filtered through a $0.22 \mu \mathrm{m}$ filter (Millipore) and checked for bacterial contamination before use. Thereafter, $500 \mu 1$ of the filtered tissue homogenate was inoculated onto $25 \mathrm{~cm}^{2}$ flasks after removing the medium and incubated in a shaking incubator (45 rpm) at $28^{\circ} \mathrm{C}$. In control flasks, maintenance medium was used in place of tissue homogenate. After $1 \mathrm{~h}$ adsorption, $6.5 \mathrm{~mL}$ of the maintenance medium (L-15 medium with $2 \%$ FBS) was added to the FtGF flasks, which were incubated at $28{ }^{\circ} \mathrm{C}$. The inoculated flasks were checked daily for cytopathic effects (CPE). The cells from flasks exhibiting 80 - 90\% CPE were harvested along with supernatant. This cell suspension was frozen at $-80^{\circ} \mathrm{C}$ for further use. Further, to know the temperature range for CyHV-2 replication, FtGF cells were infected with CyHV-2 and incubated at 18,20 and $25^{\circ} \mathrm{C}$.For titration, FtGF cells were grown in a 96-well plate with a confluence of 200 $70 \%$ to $80 \%$. After removing the medium, filtered tissue homogenate was diluted ten-fold $\left(10^{-1}\right.$ to $10^{-9}$ ), and $0.1 \mathrm{~mL}$ of diluted filtrate was inoculated in triplicate and allowed to adsorb for $1 \mathrm{~h}$.

202 In control wells, DPBS was added in place of filtered tissue homogenate. Thereafter, $0.2 \mathrm{~mL}$ of 
203 maintenance medium was added to each well and the plate was incubated at $28{ }^{\circ} \mathrm{C}$. The wells

204 were examined daily for the appearance of CPE up to 2 weeks. The virus titer was determined by

$20550 \%$ tissue culture infective dose $\left(\mathrm{TCID}_{50}\right)$ assay using Reed \& Muench (1938) calculations. The

206 viral susceptibility and titration assays of FtGF cells were determined based on three independent

207 experiments.

208 Experimental challenge studies on goldfish using CyHV-2 propagated in FtGF cells

209 Clinically healthy goldfish $(12-15 \mathrm{~cm} ; 16-23 \mathrm{gm})$, procured from a local ornamental fish farm,

210 were divided into two groups of 30 fish each and acclimatized in the laboratory aquarium tanks

211 for a week. The tissues from randomly collected goldfish $(n=5)$ were screened for CyHV-2 using

212 PCR following Jeffery et al. (2007). The fish were anaesthetized with MS-222 (Sigma-Aldrich).

213 Fishes in the infected group were challenged with an intraperitoneal (IP) injection of $0.5 \mathrm{~mL}$ of $21410^{\text {th }}$ passage CyHV-2 FtGF cell culture supernatant, whereas fish in the control group were 215 injected with $0.5 \mathrm{~mL}$ maintenance medium. The water temperature was maintained at $28{ }^{\circ} \mathrm{C}$ 216 during the experiment and fish were observed daily for clinical signs and mortality. Three 217 goldfish each in the infected and control group were selected randomly after 7 days post218 injection (dpi) and screened for CyHV-2 by PCR assay. The experimental challenge study in fish 219 was carried out following ARRIVE guidelines and carried out in accordance with the National 220 Institutes of Health guide for the care and use of Laboratory animals. The experimental challenge 221 trials were evaluated and approved by Institute Animal ethics Committee (IAEC) of ICAR 222 National Bureau of Fish Genetic Resources (NBFGR) vide approval Number G/IAEC/2019/1 223 dated $04^{\text {th }}$ October 2019.

\section{Confirmation of the CyHV-2 virus}

225 Polymerase chain reaction 
226 The naturally infected tissues from goldfish, supernatant along with cells collected from FtGF

227 flask and infected tissues from experimentally infected goldfish were processed for confirmation

228 by PCR. The harvested FtGF cells were centrifuged and DNA was isolated from cell pellet using

229 DNeasy blood and tissue kit (Qiagen). Concentration and purity of the extracted DNA was

230 determined by measuring OD at 260 and $280 \mathrm{~nm}$ using a NanoDrop ND1000 spectrophotometer

231 (Nano Drop Technologies Inc). The samples were stored at $-20{ }^{\circ} \mathrm{C}$ for further analysis. PCR was

232 performed using published oligonucleotide primers CyHVpol-FOR and CyHVpol-REV primers

233 (Jeffery et al., 2007) for confirmation. Briefly, amplification was performed in $25 \mu 1$ reaction

234 mixture containing $2.5 \mu \mathrm{l}$ of $10 \mathrm{X}$ Taq buffer, $1.5 \mu \mathrm{l}(10 \mathrm{pmol})$ of each primer, $0.5 \mu 1$ of dNTPs $(2$

$235 \mathrm{mM}), 0.25 \mu \mathrm{l}$ of Taq DNA polymerase $\left(5 \mathrm{U}^{-1}\right), 1 \mu \mathrm{l}$ of total DNA and $\mathrm{ddH}_{2} \mathrm{O}$ to make final

236 volume to $25 \mu \mathrm{l}$. The reaction mixture was pre-heated at $95^{\circ} \mathrm{C}$ for $3 \mathrm{~min}$ followed by 40 cycles

237 of $95^{\circ} \mathrm{C}$ for $1 \mathrm{~min}$, annealing at $55^{\circ} \mathrm{C}$ for $1 \mathrm{~min}$, extension at $72{ }^{\circ} \mathrm{C}$ for $1 \mathrm{~min}$ and final extension

238 at $72{ }^{\circ} \mathrm{C}$ for $10 \mathrm{~min}$. The PCR products were visualized following electrophoresis in $1.5 \%$

239 agarose gel. Representative PCR amplicons from each primer set were purified and sequenced by

240 Sanger sequencing facility (Scigenom Pvt. Ltd). These sequences of amplified PCR products

241 from all the cases (natural infected goldfish, experimentally infected goldfish and infected FtGF

242 cells) were confirmed by BLAST analysis.

243 Histopathology

244 For histopathological examination, tissues including gills, kidney and spleen were collected from

245 moribund fish at $7 \mathrm{dpi}$ and fixed in 10\% neutral buffered formalin. Tissues were dehydrated in

246 ascending grades of ethanol, cleared in chloroform and embedded in paraffin wax. Thin tissue

247 sections, 4-5 $\mu \mathrm{m}$ thick were cut and stained with haematoxylin-eosin for examination under a 248 compound microscope. 


\section{Transmission electron microscopy}

250 The experimentally infected fish tissues and CyHV-2 infected FtGF cells were fixed with 2.5\%

251 glutaraldehyde, post fixed with osmium tetroxide for $1 \mathrm{~h}$ at $4{ }^{\circ} \mathrm{C}$, then dehydrated and embedded.

252 A microtome (Leica ultracut UCT) was used to cut thin sections of about 60-70 nm. Sections

253 were stained with uranyl acetate and alkaline lead citrate after mounting on copper grids.

254 Sections were observed and photographed under a Tecnai T12 Spirit transmission electron

255 microscope at $60 \mathrm{kV}$. Supernatant from CyHV-2 infected FtGF cells displaying CPE were

256 studied by electron microscopy. Subcultured samples were negatively stained with

257 phosphotungstic acid and examined using a High Resolution Transmission Electron Microscope,

258 (FEI-TECNAI-G2 20 TWIN) at 7800× magnification and an accelerating voltage of $120 \mathrm{kV}$.

\section{Statistical analysis}

260 In the present study, all statistical analysis of the data was performed with SPSS version 13.0

261 (IBM; www.ibm.com). All results are expressed as mean \pm SD. $P$ values $<0.05$ were considered

262 statistically significant.

\section{Results}

264 Primary cell culture and maintenance

265 The primary culture of fin cells from goldfish was achieved using L-15 medium supplemented 266 with $20 \% \mathrm{FBS}$ at $28^{\circ} \mathrm{C}$. The cells were seen emerging from the sides and edges of caudal fin 267 tissues (Fig. 1A) and they readily attached to the bottom of the flask. A monolayer culture was 268 obtained within 10 days at $28^{\circ} \mathrm{C}$. The monolayer was passaged at 1:2 ratio every 6-7 days. The 269 growth pattern of lag phase (1-3 days), log phase (3-5 days) and stationary phase (5-7 days) was 270 observed. During the initial passages, mixed fibroblast-like and epithelial-like cells were 271 observed and after 10 passages, epithelial cells dominated over fibroblastic cells (Fig. 1B). The 
272 FtGF cells have been subcultured for over 55 passages and the cell line has been designated as

273 Fantail Goldfish Fin (FtGF) cell line. The morphology of FtGF cells at $25^{\text {th }}$ passage and at $56^{\text {th }}$

274 passage are shown in Fig.1 C \& D.

\section{Characterization of FtGF cell line}

276 The FtGF cells were characterized to determine the ability to grow at different temperatures and

277 different concentrations of FBS, to check the chromosome number of the cells, to authenticate

278 the species origin by DNA barcoding, to examine for the Mycoplasma contamination, to confirm

279 the nature of the cells by immunofluorescence test and to check the transfection efficiency of the 280 cells. The most favourable conditions for culturing of FtGF cells were tested at different 281 incubation temperatures including $20,24,28,35$ and $37^{\circ} \mathrm{C}$ as well as at different concentrations 282 of FBS viz., 5, 7.5, 10, 15 and $20 \%$. The cells incubated at 20 and $37{ }^{\circ} \mathrm{C}$ showed rounding and 283 started detaching on $2^{\text {nd }}$ day. Cells grew in the flask at $24{ }^{\circ} \mathrm{C}$, but the growth rate was slow. 284 Maximum growth of the cells was observed at $28{ }^{\circ} \mathrm{C}$. At $35^{\circ} \mathrm{C}$, FtGF cells proliferated very fast 285 initially, but became puffy and were dying by the $2^{\text {nd }}$ day. Culture of FtGF cells grew best in L28615 with $20 \%$ FBS and a slower growth was recorded with decreasing concentration of FBS. The 287 growth kinetics of FtGF cells did not show much difference in 10, 15 and 20\% FBS, but cells in 7.5 and 5\% FBS had slower growth. The suitable temperature and FBS concentration for the 289 culture of FtGF cells were found to be $28{ }^{\circ} \mathrm{C}$ and $10 \% \mathrm{FBS}$, respectively (Fig. 2A \& B). The growth curve of FtGF cells at passage 25 (Fig. 2C) showed as typical "S" shape and the cells were at latent stage before day 1 after seeding and then the cells proliferated rapidly and went into logarithmic stage from day 1 to day 5 . The cell number remained stationary between day 5 and day 8 , but began to decline after day 9. The FtGF cells grew and proliferated at a steady rate, 
295 arrested in metaphase using Colchicine at final concentration of $1 \mu \mathrm{g} / \mathrm{mL}$. Karyotyping results

296 obtained by counting 100 spreads at metaphase showed 82-114 chromosomes, with a distinct

297 peak for the cell line at 104 diploid chromosomes at $30^{\text {th }}, 40^{\text {th }}$ and $56^{\text {th }}$ passage. The majority of

298 the cells $(60 \%)$ had a diploid chromosome number $(2 \mathrm{n}=104)$ at all three passage levels. The

299 diploid karyotype of FtGF cells and its frequency distribution at passage 30 are shown (Fig. 3A

$300 \& 3 \mathrm{~B})$ respectively. The FtGF cells at $20^{\text {th }}$ and $40^{\text {th }}$ passage were revived and these exhibited 70-

$30175 \%$ viability. The cells were incubated at $28{ }^{\circ} \mathrm{C}$ and a monolayer was established within 15

302 days. Green fluorescent signals were observed in FtGF cells transfected with $2 \mu \mathrm{g}$ of pAcGFP1-

$303 \mathrm{~N} 1$ expression vector and strong green fluorescent signals were detected at $52 \mathrm{~h}$ post transfection

304 and transfection efficiency was calculated about $28 \%$ thus confirming their potential to be used

305 in gene expression studies. (Fig.3C). The origin of FtGF cell line was confirmed by partial

306 amplification and sequencing of 16S rRNA and COI genes from FtGF cells and goldfish muscle

307 and comparison with available COI and 16S rRNA sequences in GenBank. Nucleotide sequence

308 analysis revealed $100 \%$ similarity with sequences from goldfish muscle and maximum similarity

309 (99\%) with COI (Accession number KX145542 and KX145499) and 16S rRNA sequences

310 (Accession number AJ247070, KY231826) of goldfish in GenBank. These data confirm that the

311 origin of the developed FtGF cell line is from goldfish. No target band of spacer region between

$31216 \mathrm{~S}$ and 23S rRNA of Mycoplasma was observed indicating that the FtGF cells were free of

313 Mycoplasma contamination.

\section{CyHV-2 isolation on FtGF cells and virus titration assays}

315 FtGF cells were infected with CyHV-2 and evaluated by significant CPEs observed. In this 316 study, CyHV-2 was propagated with high viral titre in the FtGF cell line. The FtGF cell line (Fig.

317 4A) infected with CyHV-2 began to show morphological changes from the $2^{\text {nd }}$ dpi (Fig. 4B) and 
318 the CPE such as cell elongation, rounding, and cell fusion with cytoplasmic vacuolation were

319 observed from $4^{\text {th }}$ dpi (Fig. 4C) at $28^{\circ}$ C. Cell death started from the $6^{\text {th }}$ dpi (Fig. 4D) and

320 complete detachment was observed by 10 days. The appearance of typical CPE in FtGF cells

321 infected with Indian CyHV-2 was observed at 8 dpi, 6 dpi and 5 dpi when the cells were

322 incubated at 18,20 and $25^{\circ} \mathrm{C}$ respectively after inoculation of the virus and it was observed that

323 the efficient propagation of Indian CyHV-2 was most rapid ( 2 dpi) at $28{ }^{\circ} \mathrm{C}$. The infected FtGF

324 cells and the supernatant were confirmed for the presence of CyHV-2 by PCR and sequencing.

325 No CPE was observed in the control cells inoculated with maintenance medium. The TCID 50 of

326 the culture suspension harvested from infected FtGF was found to be $10^{7.8 \pm 0.26} \mathrm{TCID}_{50} / \mathrm{mL}$

327 (Fig.5A). The CyHV-2 could be propagated in FtGF flasks for 20 passages.

\section{Virulence of $\mathrm{CyHV-2}$ propagated in FtGF cells to goldfish}

329 To confirm the infectivity of CyHV-2 propagated on FtGF cell line, an experimental challenge 330 study was carried out in healthy goldfish. The goldfish challenged with $1.4 \times 10^{7} \mathrm{TCID}_{50} / \mathrm{mL}$ 331 CyHV-2 (passage 10) produced in the FtGF cell line began to die at 5 days post inoculation (dpi) 332 and the mortality reached $100 \%$ at 12 dpi (Fig.5B). The dead fish from infected groups exhibited 333 similar clinical signs seen in naturally infected fish. The clinical signs of challenged goldfish 334 were haemorrhages on the body surface, exophthalmia, pale gills and a swollen abdomen (Fig. 335 5C and D). There was no mortality in the mock-infected group. The tissues from randomly 336 selected fish from the infected groups tested positive for CyHV-2 by PCR and produced CPE in 337 FtGF, while fish from control group were negative. The CyHV-2 recovered from experimentally 338 infected fish was also found to be virulent to goldfish and caused similar symptoms (unpublished 339 data).

340 Confirmation of the CyHV-2 virus 
341 The confirmation of the CyHV-2 infection in infected tissues, FtGF cell culture suspension, and

342 experimentally challenged fish was carried out by amplification of fragment of DNA polymerase

343 gene using PCR, histopathological investigation and transmission electron microscopy.

\section{Polymerase chain reaction}

345 Tissue samples (gills, spleen and kidney) collected from naturally infected tissues, FtGF cell

346 culture suspension, and experimentally challenged fish were found to be positive for CyHV-2 in

347 PCR assay. The expected PCR product of 362 bp was obtained in all CyHV-2 positive samples.

348 A GenBank BLAST search on the sequence revealed a high identity to CyHV-2 isolate SYC1

349 strain (KM200722, 99.9\%) and CyHV-2 isolate STJ1 strain (JQ815364, 99.9\%). The sequence

350 of the DNA polymerase gene of CyHV-2 isolated from goldfish in this study was deposited in

351 GenBank (GenBank accession nos. KU527548 and KU527549).

\section{Histopathology}

353 Hypertrophied nuclei with marinated chromatin material in sections of gills, spleen and kidney 354 from goldfish experimentally infected with CyHV-2 (Fig. 6A, B \& C) and inflammatory exudate 355 between the secondary lamellae were observed in sections of gills. The lesions of the 356 experimentally challenged fish were compared with the sections of gills, spleen and kidney in 357 naturally CyHV-2 infected goldfish.

\section{Transmission electron microscopy}

359 The mature virus particles were observed ultra structurally in cytoplasm of cells in gills as well 360 as spleen tissue of experimentally challenged fish (Fig. 7A \& B) and CyHV-2 infected FtGF 361 cells that were about $170-180 \mathrm{~nm}$ in diameter (Fig. 7C). Supernatant of FtGF cells with CPE 362 were examined by TEM, and viral particles morphologically similar to a herpesvirus were 363 observed (Fig. 7D). 


\section{Discussion}

365 The ease of detecting and isolating the virus using cell lines provides a remarkable advantage in

366 viral disease management. Isolation of virus in cell culture has been considered as the "gold

367 standard" for the viral disease diagnosis for decades. It would be a valuable approach when a

368 viable virus isolate is needed and also to differentiate nonviable virus in a clinical specimen.

369 Over the past few years, a number of fish viruses viz., viral nervous necrosis virus (Azad et al.,

370 2005), iridovirus (George et al., 2015), cyprinid herpesvirus-2 (Sahoo et al., 2016), and carp

371 edema virus (Swaminathan et al., 2016a), have been reported from India and some of these have

372 also been isolated using fish cell lines. As CyHV-2 mainly affects goldfish, development of

373 species-specific cell line will greatly aid in disease health management. Several cell lines have

374 been employed for isolation of CyHV-2 (Rougée et al., 2007; Yan et al., 2011; Ito et al., 2013;

375 Ma et al., 2015; Jing et al., 2016). In India, Sahoo et al. (2016) isolated CyHV-2 using a koi carp

376 cell line, CCKF but could not propagate the virus beyond $4^{\text {th }}$ passage. The continuous culture of

377 CyHV-2 has been challenging due to the lack of permissive cell lines in India. In this paper, we

378 have demonstrated the continuous propagation of CyHV-2 using FtGF cell line as well as

379 successful experimental infection of goldfish by intraperitoneal injection with the CyHV-2

380 propagated in FtGF cells.

381 The caudal fin has the feature of natural regeneration capacity (Akimenko et al., 2003)

382 accounting for a high in vitro cell proliferation potential (Santos-Ruiz, Santamaria \& Becerra,

383 2005). The FtGF cell line exhibited stable growth over about 55 passages over the past one year.

384 Using the new cell line, we isolated CyHV-2 using filtered tissue homogenate from infected

385 goldfish. Morphological changes in FtGF cells infected with CyHV-2 included cytoplasmic

386 vacuolation, rounding and detachment of cells, as reported previously in other CyHV-2 infected 
387 cells. Moreover, CyHV-2 could be continuously propagated over 20 times using FtGF cell line 388 and also consistently produced the similar CPE as the initial passage. Similar to our results, Ma 389 et al. (2015) could also propagate the virus for over 50 passages in GiCB cell line. However, in 390 contrast to our results, Jung \& Miyazaki (1995) reported that using epithelioma papulosum 391 cyprini and FHM cell cultures; CyHV-2 could not be sub-cultured beyond the fourth passage. 392 Previously, several attempts have been made to propagate CyHV-2 in different fish cell lines (Li 393 \& Fukuda, 2003; Waltzek et al., 2005; Jeffery et al., 2007; Ito et al., 2013; Xu et al., 2013; Jing 394 et al., 2017) but it has not been possible to propagate CyHV-2 beyond 4-6 passages and virus 395 titre from these cells was very low.

396 In the present study, efficient propagation of CyHV-2 with high viral titre was achieved when the 397 infected FtGF cells was incubated at $28{ }^{\circ} \mathrm{C}$. Jeffery et al. (2007) isolated CyHV-2 from extracts 398 of gill tissue in KF-1 cells at $20^{\circ} \mathrm{C}$, whereas, $\mathrm{Xu}$ et al. (2013) observed CPE by CyHV-2 at 10 399 dpi on the KF cell line when incubated at $25^{\circ} \mathrm{C}$. Similarly, CPE by CyHV-2 was observed at 6 400 dpi in GFF and SRTF cell cultures (Ito et al., 2013) and GiCB cells (Ma et al., 2015) when 401 incubated at $25^{\circ} \mathrm{C}$. The virus titer was estimated at $10^{7.8 \pm 0.26} \mathrm{TCID}_{50} / \mathrm{mL}$, which is much higher 402 than any earlier reported titer for CyHV-2 in other studies. In this study, the removal of cell 403 culture medium from the flask before inoculating the tissue homogenate in FtGF cells, 404 incubation temperature and shaking during adsorption of the viral inoculum, might have 405 increased the viral titre of CyHV-2 in FtGF cell line. Ma et al. (2015) reported that the CyHV-2 406 titer reached $10^{7.5 \pm 0.37} \mathrm{TCID}_{50} / \mathrm{mL}$ and has been effectively cultured over 50 times in the GiCB 407 cell line. Ito et al. (2013) reported that incubation temperature of $25^{\circ} \mathrm{C}$ is considered to be highly 408 tolerant for isolation of CyHV-2 in GFF cells. But, in our study, we got high CyHV-2 tire of $40910^{7.8 \pm 0.26} \mathrm{TCID}_{50} / \mathrm{mL}$ at $28{ }^{\circ} \mathrm{C}$ which is a high incubation temperature. In accordance with our 
410 results, Piaskoski, Plumb \& Roberts (1999) and McClenahan, Beck \& Grizzle (2005) found that

411 incubating the cells inoculated with the largemouth bass virus (LMBV) samples at $30{ }^{\circ} \mathrm{C}$ resulted

412 in a higher number of LMBV plaques than incubation at $25^{\circ} \mathrm{C}$ or $32{ }^{\circ} \mathrm{C}$. Similarly, Chi et al.,

413 (1999) also found that the optimum temperature range for grouper nervous necrosis virus

414 (GNNV) infection in GF-1 cells was $24-32{ }^{\circ} \mathrm{C}$ and virus titer increased with an increase of the

415 temperature. The removal of tissue culture medium might have made the virus concentration

416 higher during adsorption and agitation resulting in a more uniform distribution of the viral

417 inoculum among all the FtGF cells in the flasks. The isolate of CyHV-2 in this study showed a

418 different temperature range for its culture compared to other published reports by various

419 workers discussed earlier. One of the possible explanations could be that the present Indian

420 CyHV-2 might belongs to a different strain or genotype or it could be due to an adaptation of the

421 host fish species to the native environmental temperature (Ciulli et al., 2006).

422 An experimental infection in goldfish was carried out with the virus passaged 10 times in FtGF 423 cells. In this experiment, fish injected IP with the cell culture grown virus, began to die at 5 dpi

424 and the cumulative mortality reached $100 \%$ at 12 dpi. This finding is in accordance with a 425 previous report (Ito et al., 2013), where cumulative mortality of 90 (at 16 dpi) and 100\% (at 18 426 dpi) were observed in Edonishiki and Ryukin goldfish varieties, respectively. In addition, Ma et 427 al. (2015) reported cumulative mortality of $100 \%$ at 14 dpi in healthy gibel carp challenged with 428 CyHV-2 (passage 9) produced in the GiCB. The CyHV-2 virus re-isolated from experimentally 429 infected fish in FtGF cells was also pathogenic to goldfish and caused disease in goldfish. In the 430 present study, the electron microscopic observations demonstrated mature virus particles similar 431 to herpesvirus in affected gill and spleen tissues from the experimentally challenged goldfish and 432 these findings are consistent with previous reports (Jeffery et al., 2007; Wu et al., 2013; Ma et 
433 al., 2015). CyHV-2 cultured in FtGF passages has been stored in liquid nitrogen. The recovered

434 viruses from liquid nitrogen maintained high infection activity to cells (data not shown). The

435 results indicated that the FtGF cell line is capable of producing high concentrations of CyHV-2

436 in vitro and a highly permissive to the propagation of CyHV-2.

\section{Conclusion}

438 In conclusion, the newly established FtGF cell line is highly susceptible to CyHV-2 culture in 439 vitro. The newly developed FtGF cell line would play a crucial role in future research on CyHV440 2, including studying the molecular pathogenesis of HVHN disease and development of 441 strategies for the prevention and control of the disease in the country. The FtGF cell line (NRFC 442 accession number: NRFC058; http://mail.nbfgr.res.in/nrfc/cellline-available.php) was deposited 443 in the National Repository of Fish Cell Line (NRFC) (the largest fish cell line repository), ICAR 444 National Bureau of Fish Genetic Resources, India for further dissemination to scientists for 445 carrying out research in developing CyHV-2 management strategies in this field.

446 Ethical statement: All the experimental challenge procedures in this study (Proposal number:

447 NBFGR/IAEC/2019/0014) were evaluated and approved by Institute Animal ethics Committee 448 (IAEC) of ICAR National Bureau of Fish Genetic Resources (NBFGR) (CPCESA Registration 449 No: 909/GO/Re/S/05/CPCSEA dated 09.09.2005 and CPCSEA Ref file No. 25/111/2014450 CPCESA dated $05^{\text {th }}$ December 2018) vide approval Number G/IAEC/2019/1 dated 04 ${ }^{\text {th }}$ October 4512019.

452 Acknowledgements

453 The authors express their thanks to Director, ICAR-National Bureau of Fish Genetic Resources, 454 Lucknow and Deputy Director General (Fy. Sc.), Indian Council of Agricultural Research 455 (ICAR), New Delhi for their support, guidance and encouragement. This research was carried 
456 out under ICAR National Fellow Scheme of ICAR (ICAR letter no F.No Agri.edn.27/2/2015

457 HRD dated 13.02.2017), Department of Agricultural Research and Education, Ministry of 458 Agriculture and Farmer's Welfare, Government of India. Authors thank Rahul G Kumar, 459 PMFGR Centre, ICAR NBFGR for correcting English language of this MS. We thank the 460 Department of Gastroenterology, Christian Medical College, Vellore, India and High Resolution 461 Transmission Electron Microscope Facility, Vellore Institute of Technology, Vellore, India for 462 the TEM analysis of the samples.

\section{References}

464

465

466

467

468

469

470

471

472

473

474

475

476

477

478

Adamek M, Hellmann J, Jung-Schroers V, Teitge F, Steinhagen D. 2018. CyHV-2 transmission in traded goldfish stocks in Germany-A case study. Journal of Fish Diseases 41(2):401404.

Akimenko MA, Marí-Beffa M, Becerra J, Géraudie J. 2003. Old questions, new tools, and some answers to the mystery of fin regeneration. Developmental dynamics: an official publication of the American Association of Anatomists 226(2):190-201.

Akimoto K, Takaoka T, Sorimachi. K. 2000. Development of a Simple Culture Method for the Tissues Contaminated with Microorganisms and Application to Establishment of a Fish Cell line. Zoological science 17: 61-63.

Altschul SF, Gish W, Miller W, Myers EW, Lipman DJ. 1990. Basic local alignment search tool. Journal of Molecular Biology 215(3):403-410.

Azad IS, Shekhar MS, Thirunavukkarasu AR, Poornima M, Kailasam M, Rajan JJS, Ali SA, Abraham M, Ravichandran P. 2005. Nodavirus infection causes mortalities in hatchery produced larvae of Lates calcarifer: first report from India. Diseases of Aquatic Organisms 63(2-3):113-118. 
479 Chi SC, Lin SC, Su HM, Hu WW, Hu WW. 1999. Temperature effect on nervous necrosis 480 infection in grouper cell line and in grouper larvae. Virus Research 63(1-2):107-14.

481

482

483

484

485

486

487

488

489

490

491

492

493

494

495

496

497

498

499

Ciulli S, Gallardi D, Scagliarini A, Battilani M, Hedrick R.P, Prosperi S. 2006. Temperaturedependency of Betanodavirus infection in SSN-1 cell line. Diseases of Aquatic Organisms. 68(3):261-265.

Freshney, R.I. (2010) Culture of animal cells: a manual of basic technique. Willey-Liss Inc., $6^{\text {th }}$ Edition, New York, 486.

Fryer JL, Lannan CN. 1994. Three decades of fish cell culture: a current listing of cell lines derived from fishes. Journal of Tissue Culture Methods 16(2):87-94.

George MR, John KR, Mansoor MM, Saravanakumar R, Sundar P, Pradeep V. 2015. Isolation and characterization of a ranavirus from koi, Cyprinus carpio L., experiencing mass mortalities in India. Journal of Fish Diseases 38(4):389-403.

Ito T, Kurita J, Ozaki A, San M., Fukuda H, Ototake M. 2013. Growth of cyprinid herpesvirus-2 (CyHV-2) in cell culture and experimental infection of goldfish Carassius auratus. Diseases of Aquatic Organisms 105(3):193-202.

Jeffery KR, Bateman K, Bayley A, Feist SW, Hulland J, Longshaw C, Stone D, Woolford G, Way K. 2007. Isolation of a cyprinid herpesvirus-2 from goldfish, Carassius auratus (L.), in the UK. Journal of Fish Diseases 30(11):649-656.

Jing H, Gao L, Zhang M, Wang N, Lin X, Zhang L, Wu S. 2016. Establishment from the snout and kidney of goldfish, Carassius auratus, of two new cell lines and their susceptibility to infectious pancreatic necrosis virus. Fish physiology and biochemistry 42(1):303-311. 
500 Jing H, Lin X, Xu L, Gao L, Zhang M, Wang N, Wu S. 2017. Establishment and characterization 501 of a heart-derived cell line from goldfish (Carassius auratus). Fish physiology and 502 biochemistry 43(4):977-986.

503 Jio GJ, Magnavitja FJ, Rubin A, Beckert WMH. 1973. Characteristics of an established goldfish 504 Carassius auratus (L.) cell line. Journal of. Fish Biology 5:315-321.

505 Jung SJ, Miyazaki T. 1995. Herpesviral haematopoietic necrosis of goldfish, Carassius auratus 506 (L.). Journal of Fish Diseases 18(3):211-220.

507 Kroeker HM. 1964. The establishment and maintenance of goldfish cell lines in tissue culture. $508 \quad$ Master's Theses. 1968. https://ecommons.luc.edu/luc theses/1968.

509 Landry ML. 2009. Primary isolation of viruses. In: Clinical Virology Manual, Fourth 510 Edition, American Society of Microbiology, pp. 36-63.

511 Lee LEJ, Caldwell SJ and Gibbons J. 1997. Development of a cell line from skin of goldfish, 512 Carassius auratus, and effects of ascorbic acid on collagen deposition, Histochemical $513 \quad$ Journal 29:31-43.

514 Li X, Fukuda H. 2003. In vitro culture of goldfish cell sensitive to goldfish herpesvirus. Journal $515 \quad$ of Shanghai Fish University 12:12-18.

516 Li X, Fukuda H. 2003. In vitro culture of goldfish cell sensitive to goldfish herpesvirus. Journal 517 of Shanghai Fisheries University 12(1):12-18.

518 Ma J, Jiang N, LaPatra SE, Jin L, Xu J, Fan Y, Zhou Y, Zeng L. 2015. Establishment of a novel 519 and highly permissive cell line for the efficient replication of cyprinid herpesvirus-2 520 (CyHV-2). Veterinary microbiology 177(3):315-325.

521 McClenahan SD, Beck BH, Grizzle JM. 2005. Evaluation of cell culture methods for detection of 522 largemouth bass virus. Journal of Aquatic Animal Health 17(4):365-372. 
523 Miller SA, Dykes DD, Polesky HFRN. 1988. A simple salting out procedure for extracting DNA

$524 \quad$ from human nucleated cells. Nucleic Acids Research 16(3):1215.

525 Palumbi SR, Martin A, Romano S, McMillan WO, Stice L, Grabowski G. 1991. The Simple

526 Fool's Guide to PCR, Version 2.0, privately published document compiled by S.

527 Palumbi. Dept. Zoology, Univ. Hawaii, Honolulu, HI, 96822.

528 Piaskoski TO, Plumb JA, Roberts SR. 1999. Characterization of the largemouth bass virus in cell culture. Journal of Aquatic Animal Health 11(1):45-51.

Reed LJ, Muench H. 1938. A simple method of estimating fifty per cent endpoints. American Journal of Epidemiology 27(3):493-497.

532

533

534

535

536

537

538

539

540

541

542

543

544

Rougee L, Ostrander GK, Richmond RH, Lu Y. 2007. Establishment, characterization, and viral susceptibility of two cell lines derived from goldfish Carassius auratus muscle and swim bladder. Diseases of Aquatic Organisms 77(2):127-135.

Sahoo PK, Swaminathan TR, Abraham TJ, Kumar R, Pattanayak S, Mohapatra A, Rath SS, Patra A, Adikesavalu H, Sood N, Pradhan PK, Das BK, Jayasankar P, Jena JK. 2016. Detection of goldfish haematopoietic necrosis herpes virus (cyprinid herpesvirus-2) with multi-drug resistant Aeromonas hydrophila infection in goldfish: First evidence of any viral disease outbreak in ornamental freshwater aquaculture farms in India. Acta tropica 161:8-17.

Santos-Ruiz L, Santamaria JA, Becerra J. 2005. Cytoskeletal dynamics of the teleostean fin ray during fin epimorphic regeneration. Differentiation 73(4):175-187.

Swaminathan TR, Kumar R, Dharmaratnam A, Basheer V.S, Sood N, Pradhan PK, Sanil NK, Vijayagopal P, Jena JK. 2016a. Emergence of carp edema virus in cultured ornamental koi carp, Cyprinus carpio koi, in India. Journal of General Virology 97(12):3392-3399. 
545 Swaminathan TR, Kumar R, Jency PME, Charan R, Syamkrishnan MU, Basheer VS, Sood N, 546 Jena JK. 2016b. A new fish cell line derived from the caudal fin of freshwater angelfish

547

548

549

550

551

552

553

554

555

556

557

558

559

560

561

562

563

564

565

566

567 Pterophyllum scalare: development and characterization. Journal of Fish Biology 89(3):1769-1781.

Waltzek TB, Kelley GO, Stone DM, Way K, Hanson L, Fukuda H, Hirono I, Aoki T, Davison AJ, Hedrick RP. 2005. Koi herpesvirus represents a third cyprinid herpesvirus (CyHV-3) in the family Herpesviridae. Journal of General Virology 86(6):1659-1667.

Wang L, He J, Liang L, Zheng X, Jia P, Shi X, Lan W, Xie J, Liu H, Xu, P. 2012. Mass mortality caused by cyprinid Herpesvirus-2 (CyHV-2) in Prussian carp (Carassius gibelio) in China. Bulletin of the European Association of Fish Pathologists 32(5):164-173.

Ward RD, Zemlak TS, Innes BH, Last PR, Hebert PD. 2005. DNA barcoding Australia's fish species. Philosophical Transactions of the Royal Society B: Biological Sciences 360(1462): 1847-1857.

Wu T, Ding Z, Ren M, An L, Xiao Z, Liu P, Gu W, Meng Q, Wang W. 2013. The histo-and ultra-pathological studies on a fatal disease of Prussian carp (Carassius gibelio) in mainland China associated with cyprinid herpesvirus-2 (CyHV-2). Aquaculture 412:8-13.

Xu J, Zeng L, Zhang H, Zhou Y, Ma J, Fan Y. 2013. Cyprinid herpesvirus-2 infection emerged in cultured gibel carp, Carassius auratus gibelio in China. Veterinary microbiology 166(1):138-144.

Xu Y, Zhou Y, Wang F, Ding C, Cao J, Duan H. 2019. Development of two brain cell lines from goldfish and silver crucian carp and viral susceptibility to Cyprinid herpesivirus-2. In Vitro Cellular \& Developmental Biology - Animal https://doi.org/10.1007/s11626-019$00402-y$ 
568 Yan W, Nie P, Lu Y. 2011. Establishment, characterization and viral susceptibility of a new cell

569 line derived from goldfish, Carassius auratus (L.) tail fin. Journal of fish diseases $570 \quad 34(10): 757-768$. 
Table $\mathbf{1}$ (on next page)

List of goldfish cell lines 


\begin{tabular}{|c|c|c|c|c|c|c|c|c|c|c|}
\hline $\begin{array}{l}\text { S. } \\
\text { No }\end{array}$ & $\begin{array}{l}\text { Designati } \\
\text { on of cell } \\
\text { line }\end{array}$ & Tissue & $\begin{array}{l}\text { Morphol } \\
\text { ogy }\end{array}$ & $\begin{array}{l}\text { Growth } \\
\text { Medium }\end{array}$ & $\begin{array}{l}\text { Passage } \\
\text { level }\end{array}$ & $\begin{array}{l}\text { Chrom } \\
\text { osome }\end{array}$ & $\begin{array}{l}\text { Revival } \\
\text { rate }\end{array}$ & $\begin{array}{l}\text { Viral } \\
\text { suscepti } \\
\text { bility }\end{array}$ & Country & Reference \\
\hline 1. & - & $\begin{array}{l}\text { Whole } \\
\text { fish }\end{array}$ & - & $\begin{array}{l}\text { At } 25{ }^{\circ} \mathrm{C} \mathrm{TC} \\
\text { medium } 199 \\
\text { with } 20 \% \\
\text { bovine } \\
\text { serum }\end{array}$ & 27 & - & - & - & $\begin{array}{l}\text { United } \\
\text { states of } \\
\text { America }\end{array}$ & $\begin{array}{l}\text { Kroeker, } \\
1964\end{array}$ \\
\hline 2. & - & Muscle & - & $\begin{array}{l}\text { At } 25{ }^{\circ} \mathrm{C} \mathrm{TC} \\
199 \\
\text { with } 20 \% \\
\text { bovine } \\
\text { serum }\end{array}$ & 18 & - & - & - & $\begin{array}{l}\text { United } \\
\text { states of } \\
\text { America }\end{array}$ & $\begin{array}{l}\text { Kroeker, } \\
1964\end{array}$ \\
\hline 3. & - & Heart & - & $\begin{array}{l}\text { At } 25{ }^{\circ} \mathrm{C} \mathrm{TC} \\
199 \\
\text { with } 20 \% \\
\text { bovine } \\
\text { serum }\end{array}$ & 18 & - & - & - & $\begin{array}{l}\text { United } \\
\text { states of } \\
\text { America }\end{array}$ & $\begin{array}{l}\text { Kroeker, } \\
1964\end{array}$ \\
\hline 4. & SJU-1 & $\begin{array}{l}\text { Skin } \\
\text { tissue }\end{array}$ & $\begin{array}{l}\text { fibroblast- } \\
\text { like }\end{array}$ & $\begin{array}{l}\text { At } 20^{\circ} \mathrm{C} \\
\text { Earle's basal }\end{array}$ & 110 & 94 & - & IPNV & $\begin{array}{l}\text { United } \\
\text { states of }\end{array}$ & $\begin{array}{l}\text { Rio et al., } \\
1973\end{array}$ \\
\hline
\end{tabular}




\begin{tabular}{|c|c|c|c|c|c|c|c|c|c|c|}
\hline & & & & $\begin{array}{l}\text { with } 20 \% \\
\text { FBS }\end{array}$ & & & & & America & \\
\hline 5. & GFSk-S1 & Skin & $\begin{array}{l}\text { fibroblasti } \\
\text { c }\end{array}$ & $\begin{array}{l}\text { At } 25^{\circ} \mathrm{C} \text { in } \\
\text { L- } 15 \text { with } \\
10 \% \text { FBS }\end{array}$ & $\begin{array}{l}\text { over } \\
\text { a 1-year } \\
\text { period }\end{array}$ & - & - & - & Canada & $\begin{array}{l}\text { Lee et al } \\
1997\end{array}$ \\
\hline 6. & GAKS & Scales & $\begin{array}{l}\text { epithelial } \\
\text { type }\end{array}$ & $\begin{array}{l}\text { DM } 160 \\
\text { with } \\
10 \% \text { FBS }\end{array}$ & - & - & - & - & Japan & $\begin{array}{l}\text { Akimoto et } \\
\text { al., } 2000\end{array}$ \\
\hline 7. & GFF & Fin & - & - & - & - & - & CyHV-2 & China & $\begin{array}{l}\text { Li and } \\
\text { Fukuda } \\
2003\end{array}$ \\
\hline 8. & GFM & Muscle & epithelial & $\begin{array}{l}\text { At } 30^{\circ} \mathrm{C} \text { in } \\
\text { L- } 15 \\
\text { medium with } \\
20 \% \mathrm{FBS}\end{array}$ & 35 & 104 & $92 \%$ & $\begin{array}{l}\text { IHNV, } \\
\text { SHRV, } \\
\text { SVCV, } \\
\text { CCV and } \\
\text { IPNV }\end{array}$ & $\begin{array}{l}\text { United } \\
\text { States of } \\
\text { America }\end{array}$ & $\begin{array}{l}\text { Rougée et } \\
\text { al., } 2007\end{array}$ \\
\hline 9. & GFSB & $\begin{array}{l}\text { Swim } \\
\text { bladder }\end{array}$ & $\begin{array}{l}\text { fibroblasti } \\
\text { c }\end{array}$ & $\begin{array}{l}\text { At } 30^{\circ} \mathrm{C} \text { in } \\
\mathrm{L}-15 \text { with } \\
20 \% \mathrm{FBS}\end{array}$ & 35 & 104 & $93 \%$ & - & $\begin{array}{l}\text { United } \\
\text { States of } \\
\text { America }\end{array}$ & $\begin{array}{l}\text { Rougée et } \\
\text { al., } 2007\end{array}$ \\
\hline 10. & GFTF & Tail fin & $\begin{array}{l}\text { fibroblast- } \\
\text { like }\end{array}$ & $\begin{array}{l}\text { At } 25^{\circ} \mathrm{C} \text { in } \\
\mathrm{L}-15 \text { with }\end{array}$ & 50 & 104 & $90 \%$ & $\begin{array}{l}\text { SHRV, } \\
\text { SVCV }\end{array}$ & China & $\begin{array}{l}\text { Yan et al., } \\
2011\end{array}$ \\
\hline
\end{tabular}




\begin{tabular}{|c|c|c|c|c|c|c|c|c|c|c|}
\hline & & & & $20 \%$ FBS & & & & and $\mathrm{CCV}$ & & \\
\hline 11. & SRTF & $\begin{array}{l}\text { Fin of } \\
\text { standard } \\
\text { Ryukin } \\
\text { Takafumi }\end{array}$ & - & $\begin{array}{l}\text { At } 25{ }^{\circ} \mathrm{C} \\
\text { MEM } \\
\text { with } 10 \% \\
\text { FBS }\end{array}$ & - & - & - & CyHV-2 & Japan & $\begin{array}{l}\text { Ito et al } \\
2013\end{array}$ \\
\hline 12. & RKF & $\begin{array}{l}\text { Fin of } \\
\text { Ryukin }\end{array}$ & - & $\begin{array}{l}\text { At } 25{ }^{\circ} \mathrm{C} \\
\text { MEM } \\
\text { with } 10 \% \\
\text { FBS }\end{array}$ & - & - & - & CyHV-2 & Japan & $\begin{array}{l}\text { Ito et al } \\
2013\end{array}$ \\
\hline 13. & GFSe & $\begin{array}{l}\text { Snout } \\
\text { tissue }\end{array}$ & $\begin{array}{l}\text { epithelial- } \\
\text { like } \\
\text { cells }\end{array}$ & $\begin{array}{l}\text { At } 25^{\circ} \mathrm{C} \text { in } \\
\text { M199 } \\
\text { with } 15-20 \\
\% \text { FBS }\end{array}$ & 80 & 100 & - & $\begin{array}{l}\text { SVCV, } \\
\text { GCRV, } \\
\text { IPNV- } \\
\text { SP, and } \\
\text { CyHV-2 }\end{array}$ & China & $\begin{array}{l}\text { Jing et al } \\
2016\end{array}$ \\
\hline 14. & GFKf & Kidney & $\begin{array}{l}\text { fibroblast- } \\
\text { like cells }\end{array}$ & $\begin{array}{l}\text { At } 25^{\circ} \mathrm{C} \text { in } \\
\text { M199 } \\
\text { with } 15-20 \\
\% \text { FBS }\end{array}$ & 80 & 100 & - & $\begin{array}{l}\text { SVCV, } \\
\text { GCRV, } \\
\text { IPNV- } \\
\text { SP, and } \\
\text { CyHV-2 }\end{array}$ & China & $\begin{array}{l}\text { Jing et al } \\
2016\end{array}$ \\
\hline 15. & $\mathrm{GH}$ & Heart & $\begin{array}{l}\text { Fibroblast } \\
\text {-like and }\end{array}$ & $\begin{array}{l}\text { At } 25^{\circ} \mathrm{C} \text { in } \\
\text { M199 }\end{array}$ & 95 & 100 & $90-95 \%$ & $\begin{array}{l}\text { EHNV, } \\
\text { ADIV }\end{array}$ & China & $\begin{array}{l}\text { Jing et al } \\
2017\end{array}$ \\
\hline
\end{tabular}




\begin{tabular}{|c|c|c|c|c|c|c|c|c|c|c|}
\hline & & & $\begin{array}{l}\text { epithelioi } \\
\text { d cells }\end{array}$ & $\begin{array}{l}\text { with } 10- \\
20 \% \text { FBS }\end{array}$ & & & & and BIV & & \\
\hline 16. & GFB & Brain & $\begin{array}{l}\text { fibroblasti } \\
\text { c }\end{array}$ & $\begin{array}{l}\text { At } 30^{\circ} \mathrm{C} \\
\text { in } 199 \\
\text { with } 20 \% \text { f } \\
\text { FBS }\end{array}$ & 40 & 110 & $90 \%$ & CyHV-2 & China & $\begin{array}{l}\text { Xu et al., } \\
2019\end{array}$ \\
\hline
\end{tabular}

3 IHNV - Infectious hematopoietic necrosis virus; SHRV - snakehead rhabdoviruses; SVCV- spring viraemia carp virus; CCV - channel 4 catfish virus; IPNV - Infectious pancreatic necrosis virus; CyHV-2 - cyprinid herpesvirus 2; EHNV - epizootic hematopoietic necrosis 5 virus; ADIV - Andrias davidianus iridovirus; BIV - Bohle iridovirus; L-15 - Leibovitz-15 medium; FBS - Foetal bovine serum. 


\section{Figure 1}

Photomicrographs of Fantail Goldfish (FtGF) cell line.

(A) Cells emerging from the explant of caudal fin; (B) morphology of FtGF cells at $10^{\text {th }}$ passage; (C) morphology of FtGF cells at $25^{\text {th }}$ passage; (D) morphology of FtGF cells at $56^{\text {th }}$ passage.
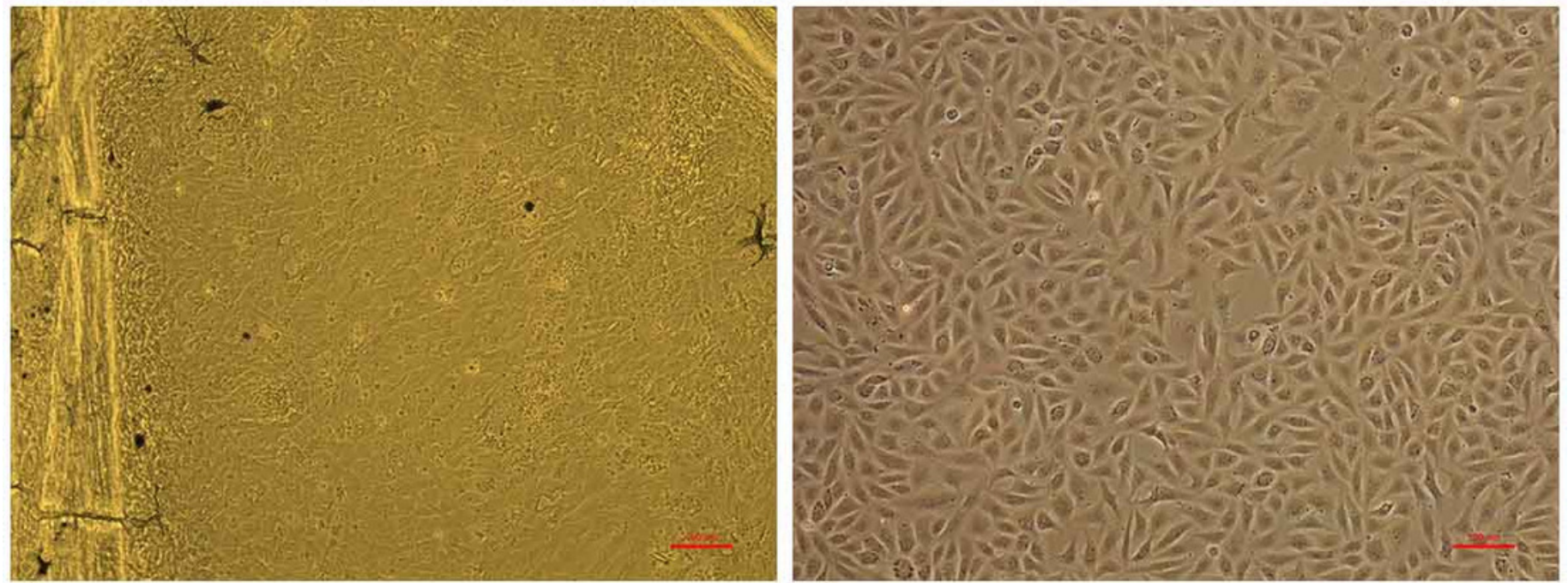

B
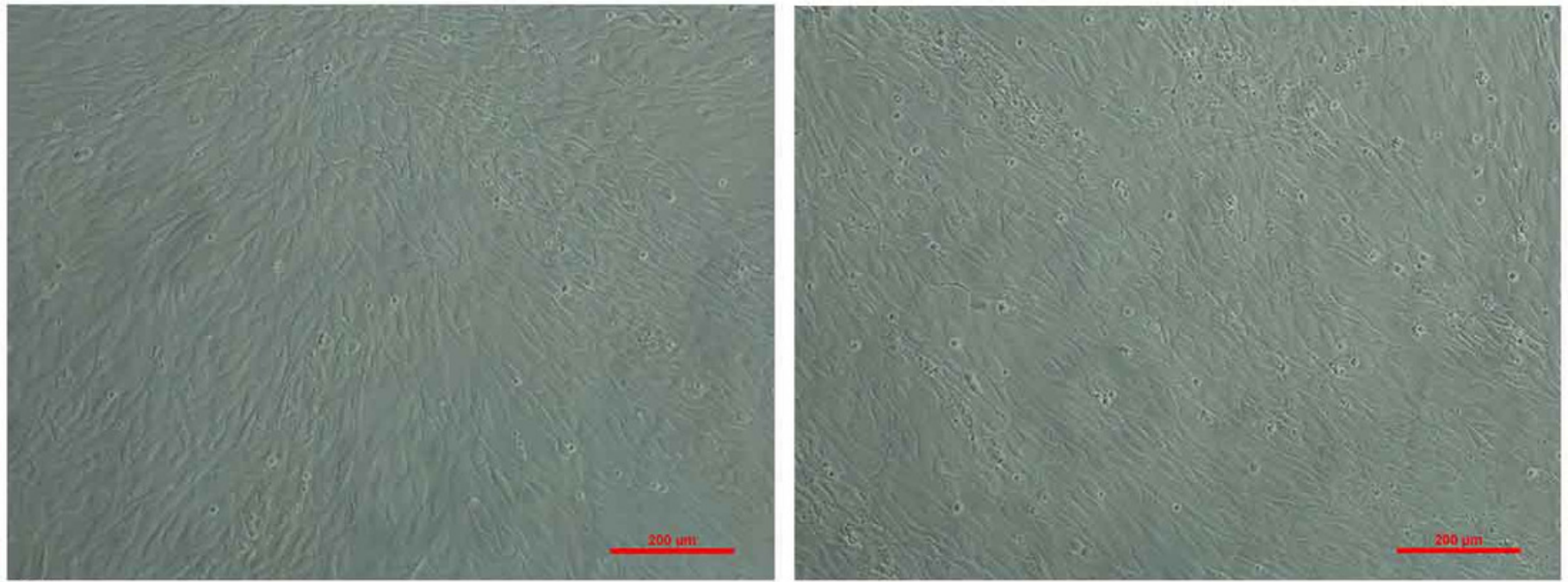

$\mathbf{C}$ 
Figure 2

Mean $\pm S D(n=2)$ growth rate of newly established FtGF cell line.

(A) Growth at different temperatures; (B) Growth at different FBS concentration; Growth curve of FtGF cell at $25^{\text {th }}$ passage with four phases including latency, exponential growth, and stationary phases. Values plotted are means \pm SD of the measurements. 

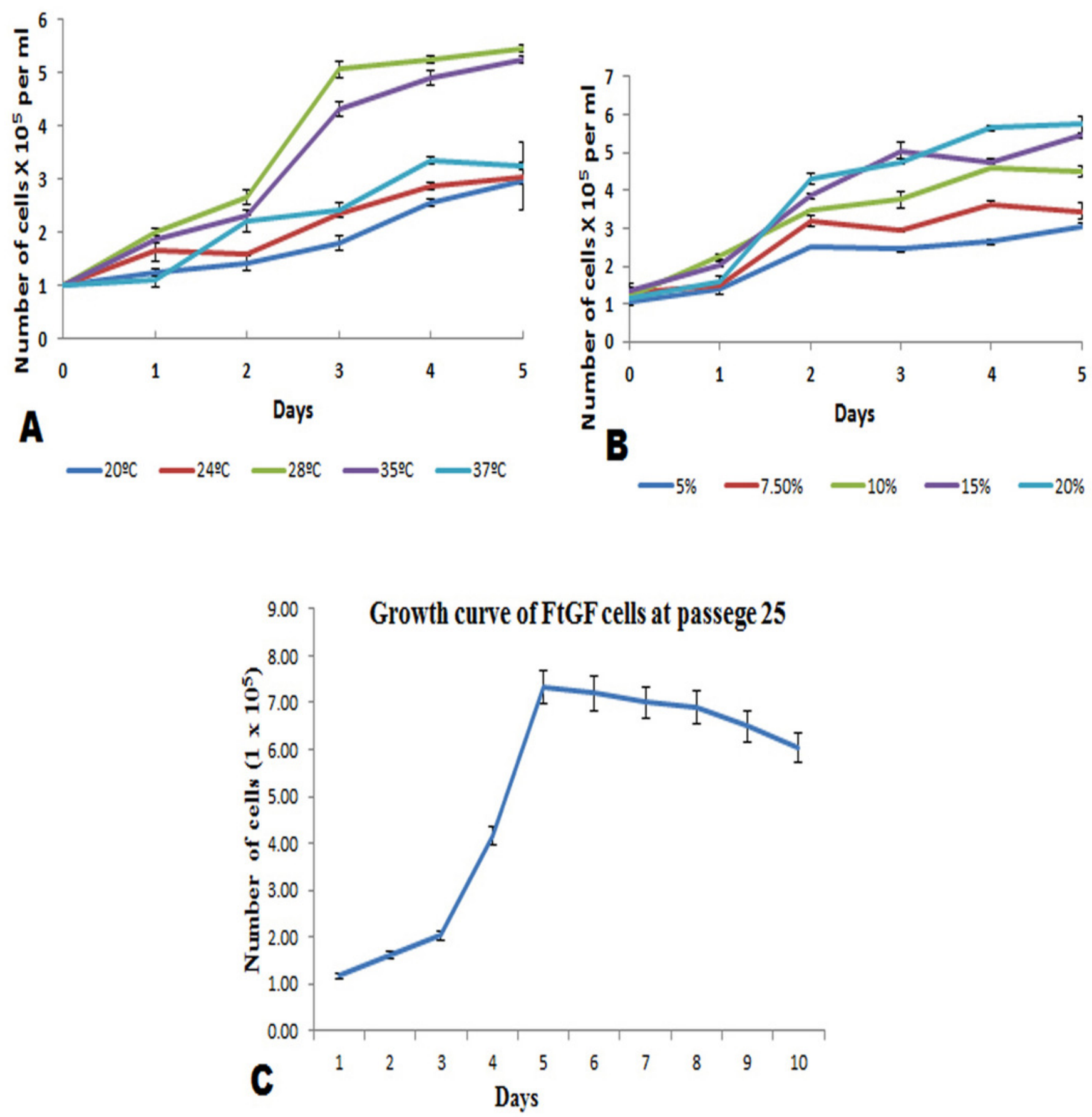
Figure 3

Morphological characteristics and frequency distribution of the chromosomes of the FtGF cell line at passage 30 and transfection efficiency of FtGF cell line.

(A) Phase-contrast photomicrograph of chromosome spread arrested in metaphase (original magnification: X400); (B) Frequency distribution of chromosomes in 100 cells; (C) Expression of green fluorescent protein (GFP) in FtGF cells at 25h passage (200X). 

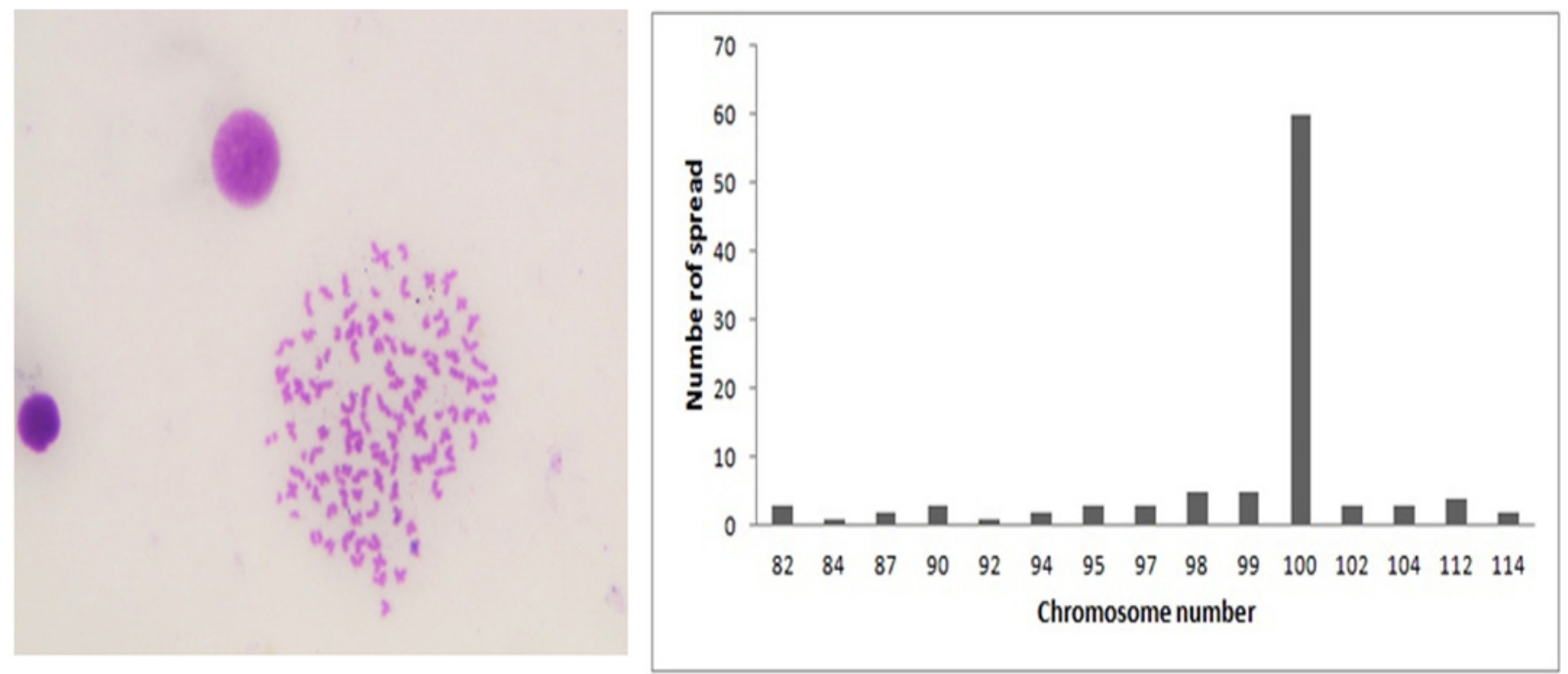

A

B

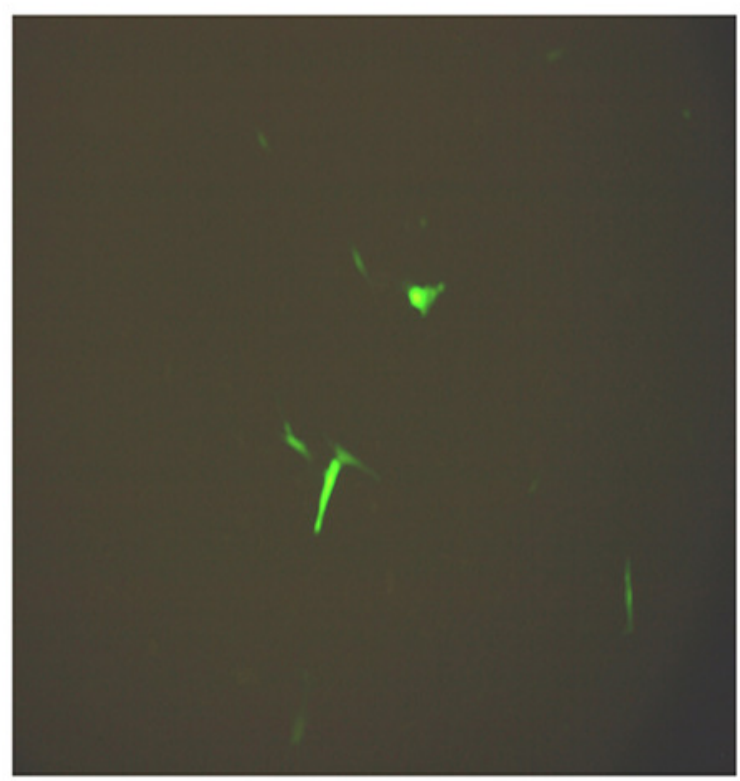

C 
Figure 4

The cytopathic effect (CPE) in FtGF cells following infection with CyHV-2 at $28^{\circ} \mathrm{C}$.

(A) Uninfected FtGF cells; (B) FtGF cells infected with CyHV-2 at passage 15 at $2 \mathrm{dpi}$; (C) FtGF cells infected with CyHV-2 at passage 15 at 4 dpi; (D) FtGF cells infected with CyHV-2 at passage 15 at $6 \mathrm{dpi}$.
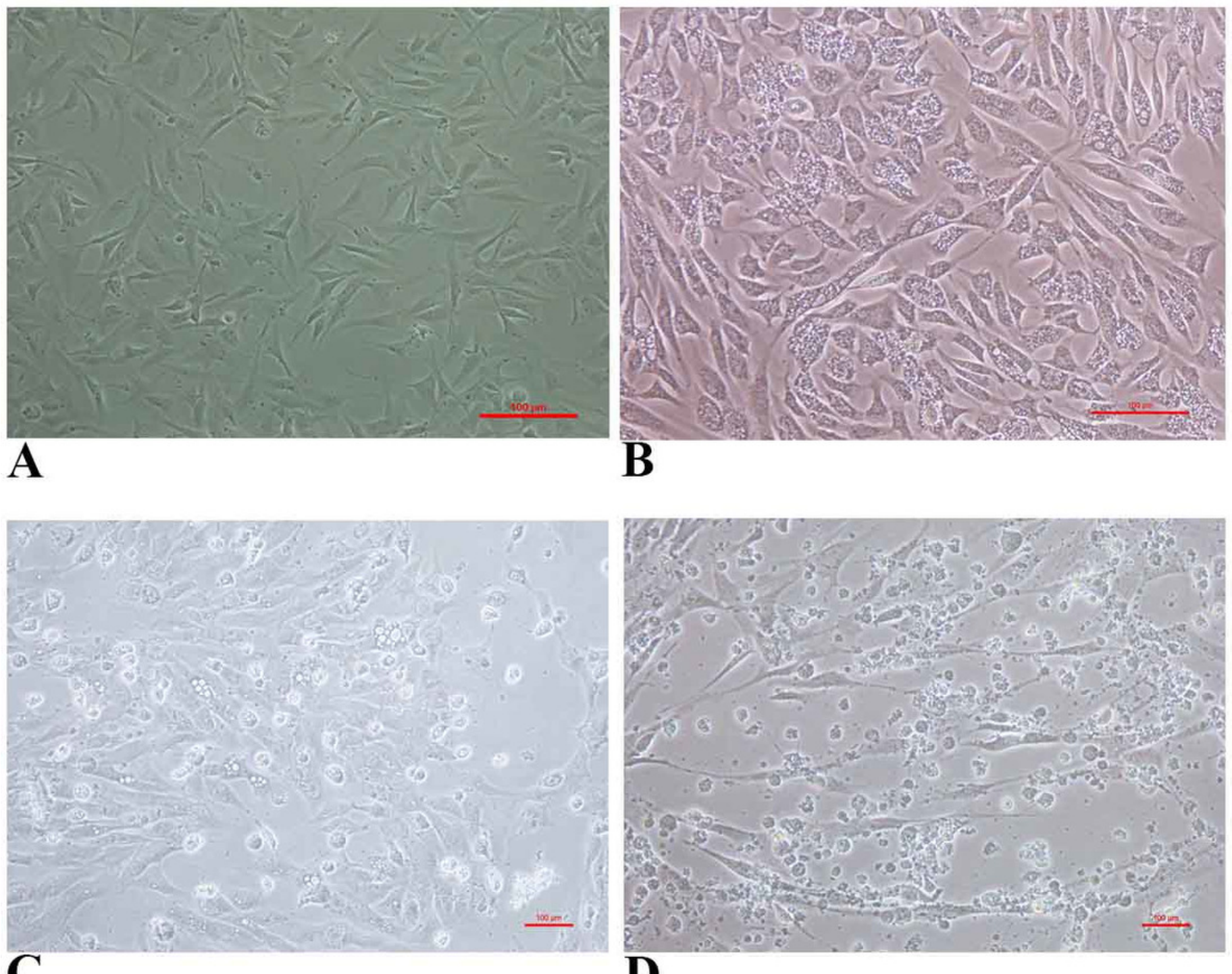

D 


\section{Figure 5}

Mean \pm SD $(n=2)$ growth curve of CyHV-2 in FtGF cell line and mortality curve of experimentally infected goldfish and gross pathology of infected goldfish.

(A) Growth curve of CyHV-2 (at passage 20) in the FtGF cell line. (B) Cumulative mortality curve of the experimentally infected goldfish (12-15 cm; 16-23 gm), using challenged with $10^{7.8 \pm 0.26} \mathrm{TCID}_{50} / \mathrm{mLCyHV}-2$ (passage 10) propagated in FtGF cells. Values plotted are means \pm SD of the measurements. (C) Experimentally challenged goldfish showing swollen body and (D) severe inflammation of gills. 

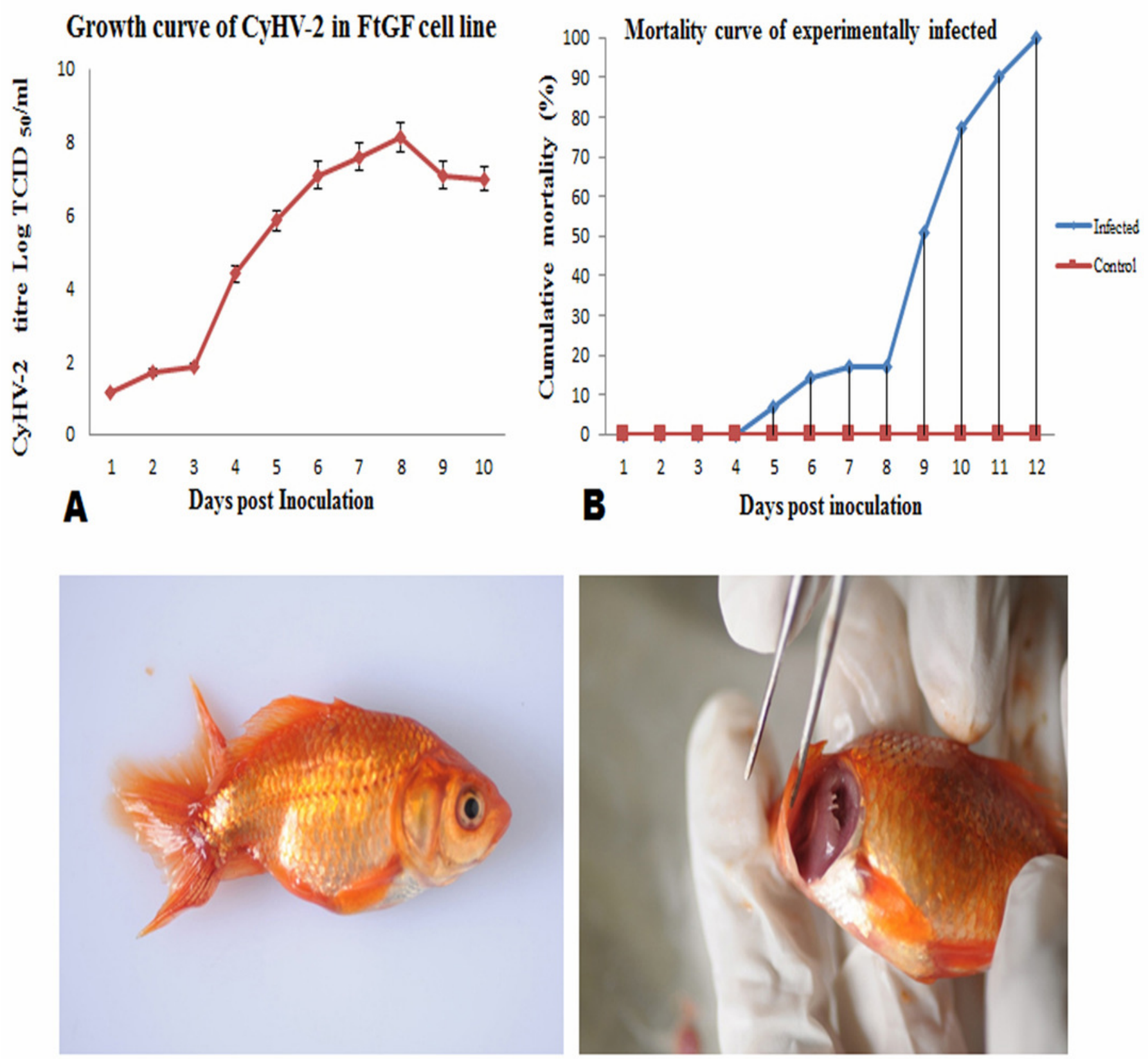

C

D 
Figure 6

Histopathological lesions in gills, spleen and kidney of a goldfish with Goldfish Herpesviral Hematopoietic Necrosis Disease. Section of goldfish gills

(A) gills; (B) spleen and (C) kidney showing margination of chromatin material (arrows).

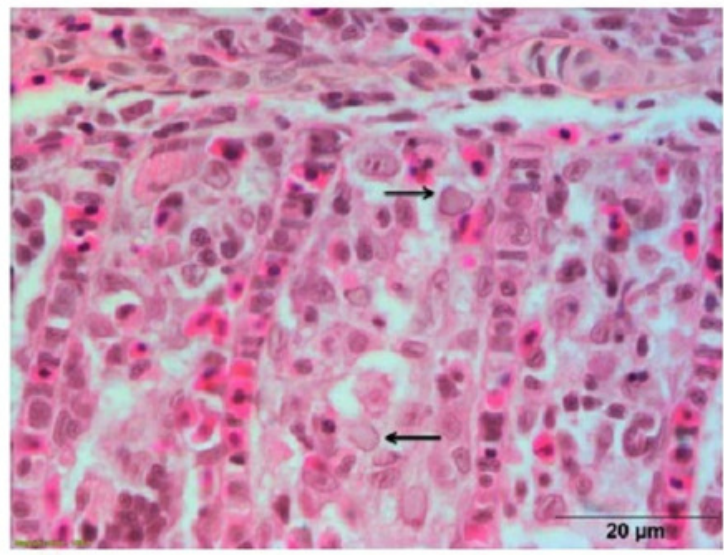

$\mathbf{A}$

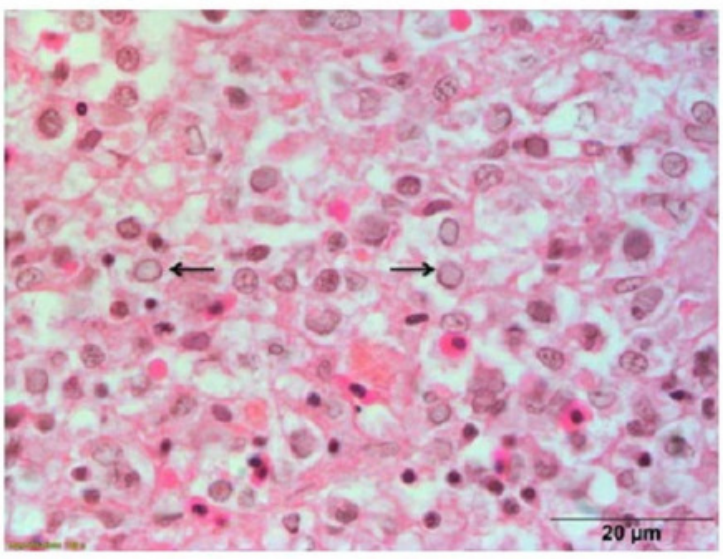

B

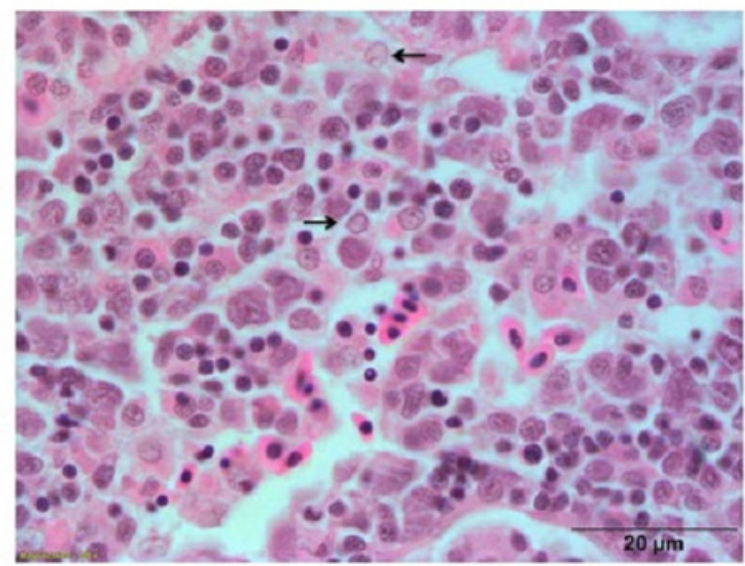

C 


\section{Figure 7}

Transmission electron micrograph showing enveloped mature CyHV-2 virions in the ultrathin sections of tissues and infeced FtGF cells

(A) gill; (B) spleen cells of experimentally challenged of goldfish and mature virus particles;

(C) CyHV-2 infected FtGF cell; (D) purified from CyHV-2 infected FtGF cells.

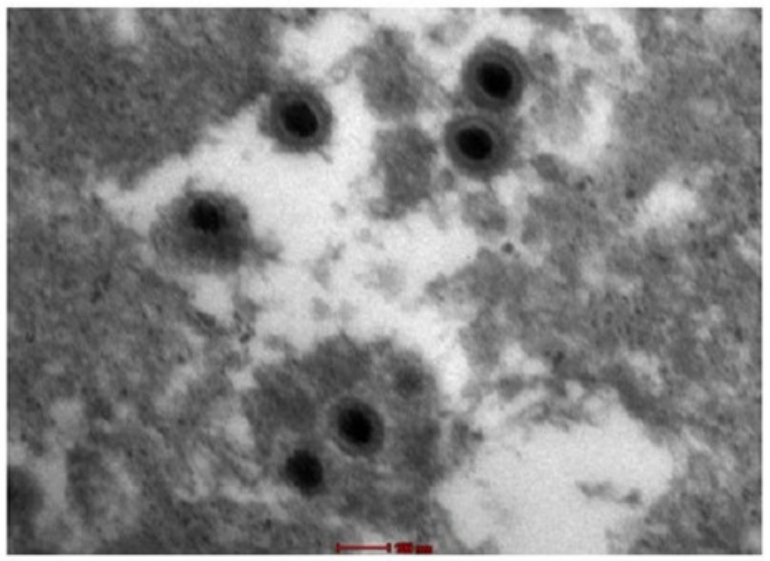

A

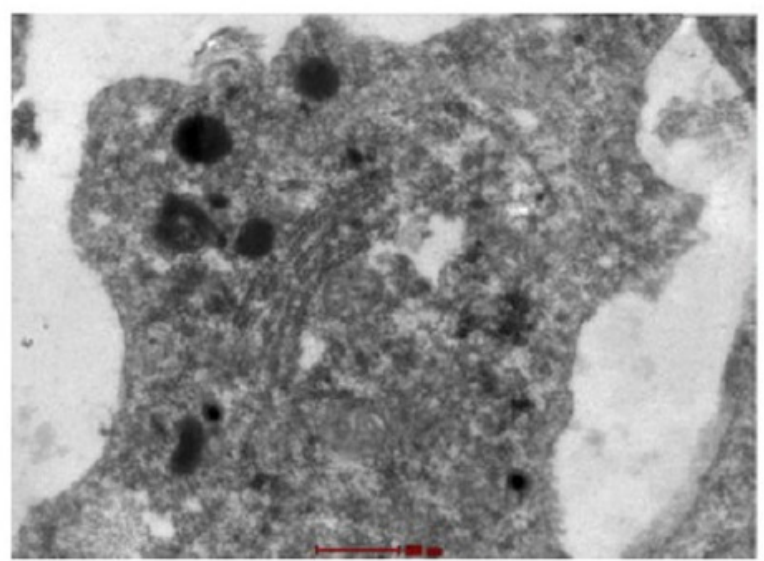

C

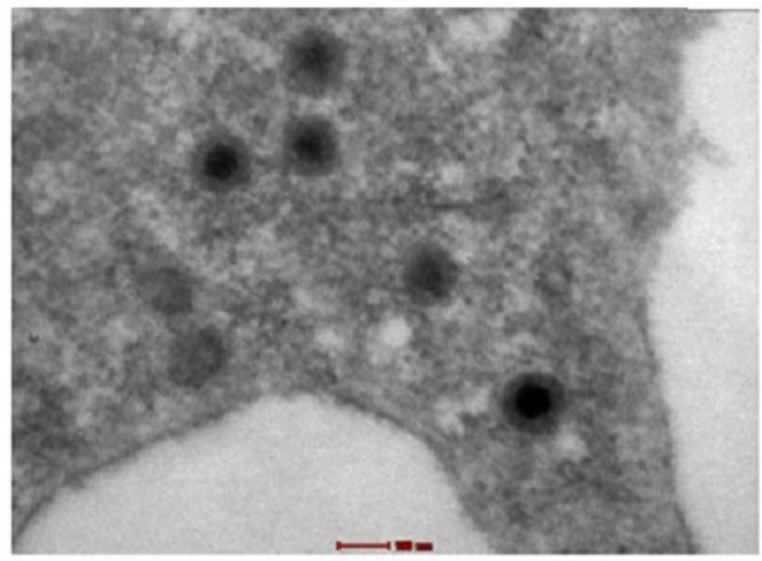

B

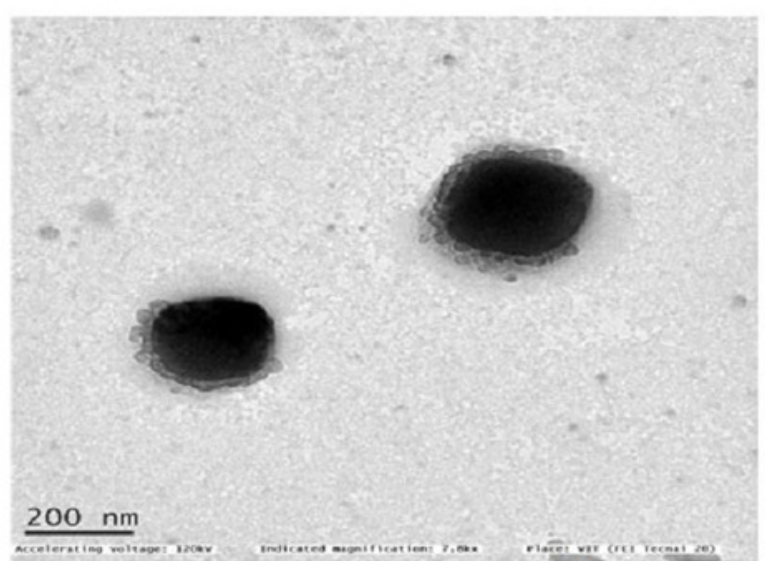

D 